\title{
SAINTIFIC APPROACH ON ISLAMIC RELIGIOUS EDUCATION CURRICULUM IN THE PERSPECTIVE OF AL-QUR'AN
}

\author{
M Hambal \\ Abu.hana.tsania@gmail.com
}

\begin{abstract}
The purpose of this study is to find out how to conceptualize scientific approaches on Islamic education curriculum, and how to analyze the scientific approach in Islamic religious education curriculum in the perspective of the Qur'an. This study used the library research method, while the data collection method used the documentation method. In data analysis or processing, the author used thematic methods. The results of this study are the concept of a scientific approach consisting of five activities including observing, asking, exploring/trying, reasoning/associating, and communicating which in relation to the perspective of Qur'an is that the five processes are demands for humans to be able to observe everything around them that is also a science, and should ask everything that has not been understood to the experts, then be able to practice or try to understand what has been received and used reason as best as possible so that there are no unfavorable perceptions that have no basis or just to conclude without any consideration of how it can strengthen that knowledge, then in the process of communicating we should be able to convey a knowledge that we have understood to others who do not understand it as in the verse, and overall it also demands in order to be able to think intellectually.
\end{abstract}

Keywords: Scientific, Curriculum and Islamic Religious Education

\section{A. INTRODUCTION}

Learning has a purpose so that all aspects of the subject can be conveyed maximum to the variety of approaches in learning. Among them is one approach that has been chosen as research material, namely the scientific approach classified as a new approach in the 2013 curriculum.

A learning also cannot be separated from a curriculum. Discussing about curriculum issues, in a nutshell it is a set of subjects and educational programs provided by an educational organizing institution that contains a lesson plan that will be given to students in one education level period.
The period in a curriculum is usually adjusted to the intent and purpose of the education system implemented. This curriculum is intended to be able to direct education towards the direction and goals intended in the overall learning activities.

In Islamic education learning there is a special curriculum, namely the Islamic education curriculum. Islamic religious education curriculum is not actually much different from the general curriculum; the difference lies only in the source of the lesson. As stated by Abdul Majid in his book Competency-Based Islamic Learning, said that the Islamic Religious Education curriculum is a formulation of the objectives, materials, 
methods and evaluation of education and evaluation of education that originates in the teachings of Islam. ${ }^{1}$

The education curriculum in Islam is functional, the purpose is not only to exclude and shape Muslim people, know religion and God, have the character of the Qur'an, but also exclude people who know life, are able to enjoy a noble life, in a free and noble society, able to give, foster, encourage and develop life of the community, through certain jobs that they mastered in. ${ }^{2}$

The aspects of Islamic teachings taught to students are selected and arranged according to their age level and the level of other knowledge they learnt. ${ }^{3}$

Principles of religious education curriculum material included, human relations with God, human relations with humans, and human relations with nature. ${ }^{4}$

In the 2013 curriculum in which there is also an Islamic religious education curriculum there has now emerged a typical approach that was followed by the 2013 curriculum. The scientific approach is a learning process designed in such a way that students actively construct concepts, laws or principles through the stages of observation (for identify or find problems), formulate problems, propose or formulate hypotheses, collect data with various techniques, observe data, draw conclusions, and communicate concepts, laws or principles "found". The scientific approach is intended to

1 Abdul Majid, Dian Andayani, Pendidikan Agama Islam Berbasis Kompetensi, (Bandung: Remaja Rosda Karya, 2004), 74.

2 Hasan Langgulung, Asas-Asas Pendidikan Islam, (Jakarta: Pustaka Al- Husna, 1988), 118.

3 Abu Ahmadi, Metodik Khusus Pendidikan Agama, (Bandung: ARMICO, 1985), 69. provide understanding to students in knowing, understanding various materials using a scientific approach, that information come from anywhere, at any time, it does not depend on unidirectional information from the teacher. Therefore, the learning conditions that are expected to be created are directed to encourage students in knowing various sources through observation, and it is not just being told. ${ }^{5}$

Learning with the scientific approach aims:

1. To improve the intellectual ability, especially the students' ability to think high-level.

2. To shape students' ability to solve a problem systematically.

3 . The creation of learning conditions where students feel that it is a necessity. 4. High learning outcomes are obtained. 5. To train students in communicating ideas, especially in writing scientific articles.

6. To develop students' character. ${ }^{6}$

The scientific approach is also called a scientific approach. The learning process can be paired with a scientific process. Because of that the 2013 curriculum mandates

the essence of a scientific approach to learning. The scientific approach is believed to be a golden platform for the development and enlargement of students' attitudes, skills and knowledge.

Learning based on a scientific approach is more effective than traditional learning. The results of the study proved that in traditional learning,

\footnotetext{
${ }^{4}$ Abu Ahmadi, Metodik Khusus, Ibid., 71

5 M Hosnan, Pendekatan Saintifik Dan Kontekstual Dalam Pembelajaran Abad 21, (Bogor: Ghalia Indonesia, 2014), 34.

${ }^{6}$ Daryanto, Pendekatan Pembelajaran Saintifik Kurikulum 2013, (Yogyakarta: GAVA MEDIA, 2014), 54
} 
the retention of information from teachers is 10 percent after 15 minutes and the acquisition of contextual understanding is 25 percent. In scientific approach-based learning, information retention from teachers is more than 90 percent after two days and the acquisition of contextual understanding is $50-70$ percent. ${ }^{7}$

Therefore, in accordance with the essence described in a book written by Daryanto, the scientific approach is good to be used in the learning process because learning outcomes are clearly better than previous learning. It is due to the scientific approach prioritizes the activeness of a student. It also due to this scientific approach is finally able to encourage an increase in students' thinking.

Regarding this subject, it has been mentioned in one of the surah in the Qur'an namely Surah Al-Insyiqaq verse 6 , as a theoretical basis for the scientific approach in the sense of the learning process contained in the approach: "O man, indeed you have worked with truly towards your Lord, then surely you will meet Him "[QS: Al-insyiqaq: 6]

The point is that humans in this world whether consciously or not, are on the way to their Lord. Surely he will meet his Lord to receive His vengeance from the good and bad deeds he has done in the world.

The journey of human life from birth to death is basically a learning process. When a baby (small), humans have begun to study. Learning to listen to those around him who said words, then learnt to say them. At first the baby was still not fluent in saying the words he

\footnotetext{
${ }^{7}$ Daryanto, Pendekatan saintifik, Ibid., 55.

${ }^{8}$ S. Margono, Metodologi Penelitian

Pendidikan, (Jakarta: Rineka Cipta, 2005), 36.
}

heard but it continued to be spoken endlessly, and finally became fluent. After a few months of age, the baby started learning to walk. The conclusion is still learning, learning anything.

In learning through the process of paying attention, hearing, asking, reasoning, trying (practicing), and associating (making networks) as well as steps in the scientific approach.

\section{B. RESEARCH METHOD}

This research is a qualitative research, which is a research procedure that produces descriptive data in the form of written or oral words from people and behavior that can be observed. ${ }^{8}$ The data collected in completing and in giving interpretation did not use numbers/statistical formulas but in the form of words extracted from books or literature.

Thus this research is more directed to literary research or library research, namely research techniques that collect data and information with the help of various kinds of material in the form of books, newspapers, magazines, journals, and several other writings that have relevance to the discussion of this research. ${ }^{9}$

This kind of literature review is usually done by collecting data or information from various library sources which are then presented in a new way or for new purposes. In this case, library materials are needed as a source of ideas to explore new thoughts or ideas, as a basis for deduction from existing knowledge, so that a new theoretical framework can be developed or as a basis for problem solving. ${ }^{10}$

\footnotetext{
${ }^{9}$ Afifuddin, Metode Penelitian Kualitatif, (Bandung: CV Pustaka Setia, 2009), 111.

${ }^{10}$ Tim Penyusun Buku Pedoman Penulisan Tesis Program Pascasarjana Universitas
} 
According to Mestika Zed explained that this literature study had 4 (four) characteristics, namely:

1 . That the researcher is dealing directly with texts or numerical data and not with knowledge from the field or eyewitnesses in the form of events, people or other objects.

2. Library data is "ready-made" (meaning readymade), meaning that the researcher does not go anywhere, except only face to face with the source material that is already available in the library.

3. Library data is generally a secondary source, in the sense that researchers obtain material from second hand and not original data from first hand in the field.

4. The condition of library data is not limited by space and time, it means that whenever it comes and goes the data will never change because it is a "dead" data stored in written reaman (text, numbers, images, recordings, tape, or film). ${ }^{11}$

According to the source, the research data is classified as primary data and secondary data. The data used by the authors in this study consisted of primary data and secondary data, namely:

a. Primary data

Primary data are sources of information that have authority and responsibility for data collection or storage or also called first-hand data/information sources, collected by researchers directly from their data sources. Primary data is also referred to as original data or new data. ${ }^{12}$ The primary data sources that I used are:

1) Ahmad Mustafa Al-Maraghi, AlQur'an and interpretation, Semarang: Toha Putra, 2003.

Muhammadiyah Surabaya, (Surabaya: , 2018), 11.

${ }^{11}$ Mestika Zed, Metode Penelitian Kepustakaan, (Jakarta: Yayasan Obor Indonesia, 2004), 4-5
2) Muhammad Qurays Shihab, Tafsir AlMisbah, Jakarta: Lantern Hearts, 2002.

3) Al-Imam Abul Fida Isma'il Ibn Kasir Ad-Dimasyqi, Tafsir Ibnu Kasir, Bandung: Sinar Baru Algensindo, 2004 b. Secondary data

Secondary data are data sources that support and complete primary data. The secondary data sources, the authors make as primary data collection, with the existence of primary data sources will further strengthen the argumentation and theoretical basis in the study. ${ }^{13}$

The secondary data in this study are several verses of Al-Qur'an, which is relevant and books that the contain is support the scientific approach in the curriculum, including:

1) Hasan Langgulung, Principles of Islamic education, Jakarta: Library AlHusna, 1988.

2) Abu Ahmadi, Special Methodology for Religious Education, Bandung: ARMICO, 1985.

3) Daryanto, 2013 Curriculum Learning Approach,

Yogyakarta: GAVA MEDIA, 2014.

The method of data analysis that the author used in this study is deductive and inductive methods, that is by analyzing a paragraph that has relevance to this discussion, then concluded the paragraph as a reinforcement of the arguments in this discussion in the form of foot notes or other quotes.

\section{RESULTS AND DISCUSSION 1. Concept of the Scientific Approach in the Islamic Education Curriculum}

\footnotetext{
12 Muhammad Ali, Penelitian Kependidikan: Prosedur dan Strategi, (Bandung: Angkasa, 1987),42.

${ }^{13}$ Joko Subagyo, Metode Penelitian Dalam Teori dan Praktek, (Jakarta: PT Rineka Cipta, 2004), cet, 4,89 .
} 
Using scientific approach must fulfill the scientific element as a scientific approach. There are several elements that must be fulfilled in the implementation, both by students and educators, namely the existence of elements, principles, scientific criteria including; Learning material that must be based on facts or phenomena that can be explained by logic or reasoning, which means that it is not prediction or imagination, to avoid them the existence of an explanation from the teacher, the response of students, and interaction between them certainly avoid the thinking of deviant learners . As well as being able to encourage students to be able to think critically and analytically, and to be able to motivate students to think hypothetically on finding the differences or similarities they get. This scientific approach also continues to fulfill the basis of concepts, theories and empirical facts that can be accounted for. The learning process must also be scientific by avoiding trial and error, as long as there is critical thinking.

While the relation with the Islamic religious education curriculum is basically the same as that applied to the general curriculum in K13. The difference is the context of the material in the learning of Islamic religious education which has certain objectives that must be instilled in students to become human beings in front of their God.

\section{Analysis of the Scientific Approach in the Al-Qur'an Perspective}

The curriculum is an educational design held by the government in order to develop all the potential for students. Besides it is used to create the most comfortable atmosphere in the teaching and learning process. The curriculum is also held to meet the response of the needs of the community who are increasingly developing all their needs and activities.

Therefore, on the basis of national education goals, the curriculum has experienced several developments, but the curriculum is also inseparable from national cultural knowledge that must remain embedded in a student. The phenomenal thing during the development of the curriculum is this latest curriculum, namely the 2013 curriculum. The indicators in the 2013 curriculum make students to be more productive, creative, innovative, affective, and happier to learn. Therefore, there are several processes in the learning activities that students must do to achieve an understanding of the material. Another term is "scientific approach".

This approach is also called the scientific approach because the process in it is paired with a scientific process. Just as the scientific method puts forward unique phenomena with specific and detailed studies to formulate general conclusions, so does the description of the learning process by applying the scientific approach that has been announced by the government in this 2013 curriculum. Here are some of the processes or activities in question, (1) the process of observing, (2) the process of asking, (3) the process of exploring/trying, (4) the process of associating/reasoning,

communicating. Some of those processes that will be examined by the researcher related to the Qur'anic perspective.

In this study the author deliberately took the Islamic religious education curriculum, but because the scientific approach only exists in the 2013 curriculum, the Islamic religious education curriculum that I mean is the Islamic religious education curriculum in K13 itself. 
Observing or paying attention to is the initial stage of a learner in the process of understanding a material or the initial process of acquiring knowledge.

The process of observing, it can be expressed by the words 'pay attention'. In observing or paying attention, humans use one of the five senses, namely the eye (sight). According to research conducted by Dr. Venon V Magnesen, humans get 30\% knowledge through seeing or paying attention.

As the Ali Imran letter verse 137 which means: "Verily, the sunnah of Allah has passed before you are; therefore, walk on the earth and pay attention to the consequences of those who reject (the apostles)".

In that verse there is an explanation that Allah commands to pay attention. Suppose to pay attention to an event in this case it can be a direct event or pay attention to an event through reading the literature. In general, humans are more impressed and easier to understand by looking directly rather than listening to explanations. For example, about the method of ablution. Children will more easily understand seeing the practice of wudlu, rather than verbal explanation (oral) about the wudlu theory.

Likewise, in the process of learning or gaining knowledge in accordance with the verses mentioned above we should also pay attention to the circumstances around us, both real events that occur in our environment directly or not. Because learning is actually not only in the classroom with a teacher but it can also be from our surroundings where we live. As the opinion of Dr. Venon, humans get knowledge through hearing only $20 \%$. So, Allah is the True One who has educated humans with the command to pay attention to get lessons or gain knowledge. In day-to-day life, we can also take lessons through observations about the lives of those who did not follow the path of Allah and His Messenger. How life or the consequences of people living life without a touch of religion can be observed, it can be seen with our own eyes. From these observations will be obtained valuable lessons.

In this observation activity students are also able to get direct experience where direct experience can better understand the students to learn a truth by making direct observations and checking the truth of the information themselves. It can also minimize the doubts that usually occur, therefore, the observer takes advantage of these observations so that there is no doubt about the correctness of the information.

Thus the writer's expression or analysis regarding verses related to the observing process in the current scientific approach. After students successfully observe or pay attention, the next stage or process that must be done is the questioning process. There will be no questions if there are no observing activities before. Because after observing an event either through reading or seeing directly questions arise automatically about things that have been observed before.

As the verse which explains the suggestion of Allah to "ask" is: "And we did not send before you, except for men we gave revelations to them; So ask someone who has knowledge if you don't know. "[QS: An-nahl: 43]

Questions are indications of a critical attitude that arises from the process of listening or estimating. This means that after someone listens, it is likely that questions will arise or even though you didn't listen before, someone 
was moved to ask after thinking or observing something.

Allah gives instructions to ask people who have knowledge. Ask specialist or experts. Questions will give birth to new sciences. Questions that cannot be answered, will encourage someone (who is asked) to find out. That is by asking people who have more skilled. Therefore, the questions trigger and spur the birth of new sciences and encourage someone to continue learning.

As the verse related to the process of asking that it is clearly stated a command word "then ask" then, it is also clear the command of Allah to his people to ask the experts (those who know) if they do not know a science.

With the questioning activity, it will appear curiosity in students, interest and attention about a theme of learning and be able to inspire and encourage students to be more active in learning and developing questions from and for themselves. It can also train students to speak fluently and encourage to be more participatory in a discussion, therefore this questioning activity is one aspect that supports the achievement of a valid understanding because it is supported from several other activities, especially in this scientific approach.

As explained in Permendikbud Number 81a year 2013, the activity of "asking" is to ask questions about information that is not understood from what is observed or questions to get additional information about what has been observed (from factual questions to hypothetical questions). ${ }^{14}$

Based on two explanations namely the interpretation of the letter An-nahl verse 43 with the statement of the Permendikbud which goes hand in hand with the process of asking, it is

\footnotetext{
${ }^{14}$ Daryanto, pendekatan pembelajaran, ibid, 65.
}

clear that the questioning process is stated in the verse of Al-Qur'an.

For the third step after observing and asking which is an information gathering activity, what is being done now is the process of trying/exploring.

Regarding the verse related to the activity or the process of exploring the writer using the letter An - Nisa 'verse 40: "Verily Allah does not persecute a person even though it is as big as a zarrah, and if there is virtue as big as zarrah, surely Allah will multiply it and give from His side a great reward. "[QS: An-nisa ': 40]

Trying means to do or practice. It is well known that Islam is a science that must be applied (applied science), not just a theory (pure science). With practice, the knowledge really sticks and animates. The more practice, the more skilled, more knowledgeable.

In relation to the religion of Islam, by practicing or practicing the shari'ah of religion, namely doing the commands of Allah and His Messenger, leaving the prohibition of Allah and His Messenger, will be righteous and religious individuals.

The connection of the verse to the process of trying or exploring the scientific approach is that Allah will not reduce the reward of those who do good even though it is as big as zarrah, even if he does good the reward will be multiplied by Allah, no matter how small it is done, it will get a reply. Who does not do anything will not get anything.

So the activity of trying or exploring is an application activity of a knowledge that has been obtained before. Trying or exploring is the same as doing something, so there is nothing in vain with what we have done so long as it is a good thing because Allah will 
reward it with a multiplied reward. In another sense after we try or explore a knowledge there will be benefits that come to us that is proven knowledge. So it is clear that the process of trying or exploring in this scientific approach has been alluded to in one verse.

In the explore or experiment activities, it is felt more memorable by a student who has done it directly, and students will better understand the nature of science and the nature of the truth directly.

The fourth activity or process carried out after observing, asking, exploring is the activity of associating or reasoning. The following is a verse that describes a reasoning activity that the author used. "Why do you have someone else (to do) a service, while you forget your own (obligation), even though you read the Book (Torah)? Then don't you think? "[QS: al-Baqarah: 110]

This verse contains a sign that humans use reason, using their minds to get the truth. Of course here contains the secret of wisdom (benefit) so that the human mind is not blunt and easily fooled. As in verse 44 of Surat AlBaqarah, Allah satirizes those who do not want to think. The person told others to do services (good), while he himself did not work. Even though he reads the book (understand). He who understands doesn't want to work, while others who don't necessarily understand are told to work. Then where is the reason.

So in the reasoning activity contained in this scientific approach is if several previous activities have been carried out which are collecting data or information or knowledge in this step we should either reflect or reason between the information or knowledge we have obtained with experiments or explorations that can be appropriate or not. We should think about it so that we can give information or validation that is truly valid to us so as not to become doubtful knowledge by us.

Because reasoning or associating is not lead us to receive information or knowledge raw. It is clear that questions, give birth to new knowledge or encourage someone to learn. Reasoning, leading someone to be smart.

So it is clear in the Al-Qur'an that we have to discuss reason as best we can if we have received information or knowledge in order to hinder bad assumptions on ourselves as Muslims. In another sense in receiving knowledge we should reason all information before we absorb it deeply without reasoning, because it will not make a science well understood.

For the last step in the learning process with a scientific approach is the activity of communicating. We can understand from the following verse: "You are the best people who are born to humans, tell the Ma'ruf (good) and prevent from the evil, and believe in Allah. If the People of the Book believe, surely it is better for them, among them there are those who believe, and most of them are the ones who are wicked. "[QS: Ali imran: 110].

The purpose of communicating here is to convey the knowledge that is already owned by others. In this context, the intention is to preach, disseminate knowledge. Because as good as the people that God created are human beings who have been equipped with reason, we should know some of our knowledge to spread to our neighbors. Because information or knowledge will also guide us to what is good and prevent us from being evil. So it's so important to spread information and knowledge to fellow creatures of God who also mean to spread goodness.

Because the sign of the best people invites to goodness, prevents evil 
actions and believes in Allah. The best humans not only preach and make speeches, but also do what they say or preach. This was revealed in a sentence "actually I am one of those who surrender themselves (Islam)" in verse 33 of Fusshilat. It means to prove themselves as

a Muslim by practicing Islamic teachings in everyday life. With this action it can be seen that he is a good Muslim.

Thus the author's explanation of the scientific approach to the Qur'anic perspective that may be far from perfection. So if it is related to our life as a Muslim, it is First to observe (pay attention). It means paying attention to the advice given by religious teachers and scholars, paying attention to the consequences of people who violate religious shari'a. The second is asking, I mean, don't just be "obedient", accept whatever the religious teacher and Islamic scholar say without asking the arguments from the Qur'an and the Sunnah. Third is trying, it means that the point is to practice what the teachings of Islam in our daily lives. The fourth is reason. It means to think about what the religious teacher and Islamic scholar have said. The fifth is to preach. Inviting the closest people and the community to study Islam, live and practice in everyday life. Because actually humans in this world whether consciously or not, are on the way to God and the five things are the process as used in the scientific approach.

\section{CONCLUSION}

Based on the results of the research that has been described, it can be concluded that: (1) The concept of a scientific approach in Islamic religious education basically returns to the purpose of education in the Qur'an that is to bring a servant closer to the creator, so the concept of scientific approach in
Islamic religious education is more developed with an understanding of everything about God to make our human beings. (2) The scientific approach is one of the approaches applied in perfecting the 2013 curriculum to meet the needs of an increasingly sophisticated society. Likewise, in the Al-Qur'an there have been several verses which explain the processes in applying the scientific approach. In the Qur'an it is clearly stated about each process of the scientific approach starting from the process of observing, asking, exploring/trying, associating/reasoning, and communicating. Basically, all processes in the scientific approach are the same as the process of human life.

\section{REFERENCES}

Majid, Abdul, Andayani Dian. Pendidikan Agama Islam berbasis Kompetensi, Bandung: Remaja Rosdakarya, 2004.

Langgulung, Hasan. Asas-asas Pendidikan Islam, Jakarta: Pustaka Al-husna, 1998.

Ahmadi, Abu. Metodik khusus pendidikan agama, Bandung: ARMICO, 1985.

Hosnan, M. Pendekatan saintifik kontekstual dalam pembelajaran abad 21, Bogor: Ghalia Indonesia, 2014.

Daryanto. Pendekatan pembelajaran saintifik kurikulum 2013, Yogyakarta: Gava Media, 2014.

Moleong, Lexy J. Metodologi penelitian kualitatif edisi revisi, Bandung: Remaja Rosdakarya, 2009.

Margono, S. Metodologi Penelitian pendidikan, Jakarta: Rineka Cipta, 2005. Afifudin. Metode penelitian kualitatif, Bandung: CV Pustaka Setia, 2009. 
Zed, Mestika, Metode Penelitian Kepustakaan, Jakarta: Yayasan Obor Indonesia, 2004.

Ali, Muhammad. Penelitian kependidikan prosedur dan strategi, Bandung: Angkasa, 1987.

Subagyo Joko, Metode penelitian dalam teori dan Praktek, Jakarta: Rineka Cipta, 2004.

Arikunto, Suharsimi. Prosedur penelitian suatu pendekatan praktek, Malang: UMM Press, 2002.

Muhajir, Noeng. Metodologi Penelitian kualitatif, Yogyakarta, PT Bayu Indra Grafika, 1996.

Bungin, Burhan, Metode penelitian kualitatif, Jakarta: Grafindo Persada, 2001.

Hadi, Sutrisno, Metode Research, Yogyakarta: Andi Offest, 1991.

Nata, Abudin, Studi Islam Komperhensif, Jakarta: Prenada Media Group, 2011.
Hamruni. Strategi Pembelajaran, Yogyakarta: Insan Madani, 2012.

Kemendikbud. Pendekatan, jenis dan metode penelitian pendidikan, Jakarta: Kemendikbud, 2013.

Kemendikbud. Diklat guru dalam rangka implementasi kurikulum 2013, Jakarta: Kemendikbud. 2013.

Langgulung, Hasan. Filsafat pendidikan Islam, Jakarta: Bulan Bintang, 1990. mustafa Al-maragi Ahmad. Tafsir Al-Maragi, Semarang: CV Toha Putra, 1993.

Shihab, M. Quraish. Tafsir Al-Misbah pesan, kesan dan keserasian AlQur'an, Jakarta: Lentera Hati, 2002.

Amirin, Tatang M. Pokok-pokok teori sistem, Jakarta: Rajawali, 1986.

Tafsir, Ahmad, Ilmu pendidikan islam, Bandung: Remaja Rosdakaraya, 2013. 